\title{
DECLARATORY RELIEF IN TUCKER ACT SUITS: A BROADENING OF THE MONEY- JUDGMENT JURISDICTION CONCEPT
}

Until recently the Court of Claims took a restricted view of the interrelationship of the Declaratory Judgment Act and its jurisdiction under the Tucker Act. Then in King v. United States these self-imposed jurisdictional limitations were disavowed, and for the first time the United States government was required to defend a declaratory judgment action relying solely on the Tucker Act to establish jurisdiction. The rationale in King, as this note interprets it, raises broad questions touching the continued viability of the sovereign immunity concept as well as more particularized procedural problems for plaintiff's who seek the newly available declaratory relief.

N THE thirty-four years since the enactment of the Declaratory Judgment Act,' federal courts have utilized this procedural remedy in an expanding number of areas, including actions against the federal government under the Suits in Admiralty Act, ${ }^{2}$ the Federal Tort Claims Act, ${ }^{3}$ and other special jurisdictional statutes. ${ }^{+}$ However, until the recent case of King $v$. United States, ${ }^{3}$ declaratory relief against the United States government in the Court

\footnotetext{
'Ch. 512,48 Stat. 955 (1934) (codified at 28 U.S.C. $\S \S 2201-03$ (1964):

"2201. Creation of remedy.

In a case of actual controversy within its jurisdiction, except with respect to federal taxes, any court of the United States, upon the filing of an appropriate pleading, may declare the rights and other legal relations of any interested party seeking such declaration, whether or not further relief is or could be sought. Any such declaration shall have the force and effect of a final judgment or decree and shall be reviewable as such.

"2202. Further relief.

Further necessary or proper relief based on a declaratory judgment or decree may be granted, after reasonable notice and hearing, against any adverse party whose rights have been determined by such judgment."

346 U.S.C. $\$ \S 741-52$ (1964).

${ }^{3} 28$ U.S.C. $\$ \S 2671-80$ (1964).

${ }^{4}$ See note 47 infra.

s 390 F.2d 894 (Ct. Cl. 1968).
} 
of Claims has been unavailable in litigation under its general jurisdictional statute, the Tucker Act. ${ }^{6}$ Heretofore, the Court of Claims has viewed its jurisdiction as limited to suits for money judgments on the technical ground that the Tucker Act contained no procedures for enforcement of non-money judgments. In King the Court of Claims, departing from established precedent, has now stated its willingness to entertain suits for declaratory judgment so long as it will enable the claimant, if he prevails, to recover money from the United States either administratively or in a later suit.

Prior to and following retirement from the Army in 1959, Colonel King attempted to convince various military boards that he should have been retired for reasons of physical disability and, thus, entitled to tax-free disability pay, rather than taxable retirement pay. ${ }^{7}$ Unsuccessful on the administrative level, King brought suit in the Court of Claims under the Tucker Act seeking a money judgment against the federal government for an amount equivalent to the income tax deducted from his longevity retirement pay. ${ }^{8}$ Without going to the merits of the assertion that the Under-Secretary of the Army had acted arbitrarily, the government argued that the suit was essentially one for a tax refund and, therefore, barred by the plaintiff's failure to file a timely refund claim. ${ }^{9}$ Following a court order

\footnotetext{
628 U.S.C. $\S \S 1346 \& 1491$ (1964).

'Although disability and retirement pay are equal in amount, the latter is taxed whereas the former is not. King was retired in 1959 for length of service pursuant to 10 U.S.C. $\$ 3911$, and his retirement pay was based on 10 U.S.C. $\S 3991$, Formula A. This entitled him to 75 percent of his monthly base pay as a colonel minus an amount withheld for income tax purposes. King contended that he should have been retired for disability pursuant to 10 U.S.C. $\S 1401$, Formula 1. If INT. Rev. CODE of 1954 \& 104(a)(4), which excludes from gross income "allowance[s] for personal injuries or sickness resulting from active service in the armed forces ...," were found to apply to such compensation, Colonel King's future pay checks would be increased by the amount withheld for federal taxes. He might even be able to obtain administratively from the Army the funds withheld from his past pay.

${ }^{8}$ Disputes over disability retirement ratings and the actions of military review and correction boards are a common-place occurrence in the Court of Claims. See, e.g., Hutter v. United States, 345 F.2d 828 (Ct. Cl. 1965); Merriott v. United States, 163 Ct. Cl. 261 (1963), cert. denied, 379 U.S. 838 (1964); Friedman v. United States, 158 F. Supp. 364 (Ct. Cl. 1958); Capps v. United States, 137 F. Supp. 721 (Ct. Cl. 1956); Lemly v. United States, 75 F. Supp. 248 (Ct. Cl. 1948).

926 U.S.C. $\$ 7422$ (a) (1964) requires the filing of a timely refund claim as a prcrequisite to a suit to recover taxes paid. A timely refund claim is one filed within three years of plaintiff's return or two years from plaintiff's payment of taxes. 26 U.S.C. § 65II(a) (1964). Apparcntly, the court reasoned that King was requesting, in effect, a return of the money withheld as tax and that this amounted to a tax refund claim. King argued that he was not requesting a refund but, rather, disability pay which he had not received. In a sense, it might be said that King was contending he had received class A pay when he was entitled to class B pay. But this ovcrlooked the fact that the pay rates for both classes are identical. Apparently, the court did not considcr
} 
upholding this defense, King and the Committee of American Steamship Lines as amicus curiae ${ }^{10}$ joined issue with the government on whether the Court of Claims had the authority to give a declaration of plaintiff's right to have his military records corrected." Acknowledging that the purpose of the Declaratory Judgment Act ${ }^{12}$ was not to expand a court's jurisdiction, the court noted that declaratory relief would not necessarily expand the classes of claims or issues within its jurisdiction. For this reason the Court concluded

the label of the pay relevant so long as the rates were the same. Had the rates been unequal, the result might have been different, because then a mere refund could not have settled the issue.

${ }^{10}$ Under the Merchant Marine Act of 1936, 46 U.S.C. $§ 1101$ (1964), United States flag lines and shipyards are subsidized by the federal government. As the U.S. flag lines must employ American seamen, they are paid an operating-differential subsidy designed to equalize their wage costs with those of their principal foreign competitors. The Act uses contracts between the United States and the ship operators as its basic operating instrument. A substantial proportion of the disputes which inevitably arise out of this maze of regulation and control relate to the obligations of the operator or of the United States under these subsidy contracts. It has been held that such disputes are subjeet to review only in the Court of Claims. See American President Lines, Ltd. v. Federal Maritime Bd., 133 F. Supp. 100 (D.D.C. 1955), aff d, 235 F.2d 18 (D.C. Cir. 1956). Under the payment procedures, a "final accounting" takes place at the end of each year. Such accountings can involve delays of prodigious proportions, sometimes three to four years. Many of these disputes involve very large amounts of money, the uncertainty of which adversely affects the financial planning of the lines. Heretofore, subsidized lines have been required to have a matured claim for a money judgment in order to institute proceedings in the Court of Claims. This, in turn, meant that no action could be taken until the completion of the annual final accounting. Thus, years might elapse before many controversies under the operatingdifferential subsidy contract could be brought to the Court of Claims for resolution. Because the availability of declaratory relief might enable subsidized operators to bring action prior to the completion of these annual final accountings, the Committee of American Steamship Lines appeared as amicus curiae.

"While the Court of Claims had never, theretofore, granted declaratory relief, federal district courts had on numerous occasions entertained suits for the declaration of a serviceman's right to have his military records changed. See, e.g., Harmon v. Brucker, 355 U.S. 579 (1958) (action against public official for declaration that plaintiff was entitled to an "honorable" discharge from the armed services); Van Bourg v. Nitze, 388 F.2d 557 (D.C. Cir. 1967) (same); Ashe v. McNamara, 355 F.2d 277 (lst Cir. 1965) (action against Secretary of the Air Force for declaration that officer was entitled to be raised on permanent retired list rather than being discharged); Ogden v. Zuckert, 298 F.2d 277 (1st Cir. 1965) (same); Bland v. Connally, 293 F.2d 852 (D.C. Cir. 1961) (action for honorable discharge). However, these declaratory judgment actions were not brought under the Tucker Act but, rather, under the jurisdictional grants of 28 U.S.C. $\S \S 1331$ (a), 1361 (1964) and within the venue limitations of 28 U.S.C. $\S 1391$ (e) (1964). In addition, these actions were not brought against the federal government but, rather, against public officials on the theory that they had exceeded their statutory powers. Nevertheless, the subjeet matter of the claims was similar to that in King in that they involved requests for corrections in military records.

${ }^{12}$ A graphic description of the benefits to be derived from deelaratory relief was given by Congressman Gilbcrt when he remarked: "Under the present law you take a step in the dark and then turn on the light to see if you stepped into a hole. Under the declaratory law you turn on the light and then take the step." 69 CONG. REC. 2030 (1928). 
that, in view of the clear language including the Court of Claims within the $\mathrm{Act}^{13}$ and the silence of legislative history on the issue, the original Act of 1934 should be read "as adequately authorizing the court to render declaratory judgments," ${ }^{1+}$ and, alternatively, that the 1948 revision should be accepted as correct. ${ }^{15}$

\section{Declaratory Relief Denied \\ While the doctrine that the United States is immune to suit without its consent ${ }^{16}$ has been a source of continuing judicial obfuscation as to when a suit is and is not against the federal}

${ }^{13}$ The Declaratory Judgment Act, 28 U.S.C. $\S 2201$ (1964) applies to "any court of the United States," which is defined in 28 U.S.C. $\$ 45 \mathrm{I}$ (1964) as including the Court of Claims. It is apparent, therefore, that the act on its face applies to the Court of Claims.

is 390 F.2d at 913.

is See notes 73 \& 74 infra and accompanying text.

${ }^{16}$ The doctrine of sovereign immunity, simply stated, is that the United States cannot be sued without its express consent. While the idea is old and its origin uncertain, Bodin, Hobbes and Machiavelli are probably the fathers of the concept that sovereignty is absolute and above the law, that the sovereign creates the law and as creator cannot be bound by the law. Thus, in England arose the maxim that "the King can do no wrong," and from this personal immunity of a single individual arose the whole concept of sovereignty. Neverthcless, the doctrinc of sovereign immunity was not expressly incorporated into the United States Constitution, nor is there anything in the Constitution that compels such a doctrine. But see Monaco v. Mississippi, 292 U.S. 313, 321 (1934). While an early Supremc Court decision rejected the concept of statc governmental immunity, see Chisholm v. Georgia, 2 U.S. (2 Dall.) 419 (1793), the effect of the decision was largely nullified by the passagc of the eleventh amendment prohibiting suit against a state in a federal court by citizens of another statc or country. Later, in Cohens v. Virginia, 19 U.S. (6 Wheat.) $264,411-12$ (1821), the Court stated: "The universally received opinion is, that no suit can be commenced or proseeuted against the United States. . . " But the Supreme Court has squarely rejected that this was an outgrowth of the maxim "the King can do no wrong." See Langford v. United States, 101 U.S. 341 (1879). And in 1882, Justice Miller observed that "the principal [of sovcreign immunity] has never been discussed or the reasons for it given, but it has always been treated as established doctrine." United States v. Lee, 106 U.S. 196, 207 (1882).

Only two justifications have ever been given by the courts for the doctrine. In Gibbons v. United States, 75 U.S. (8 Wall.) 269, 275 (1868), it was said to be a "policy imposed by necessity." This view has been shown to be fallacious in that practically every country of Western Europe has long accepted financial responsibility, with no apparcnt loss of efficient or effective governmental service. See Borchard, Governmental Liability in Tort, 34 Yale L.J. 1, 2, $9 \mathrm{n} .25,14 \mathrm{n} .45$ (1924). The other justification is that "there can be no legal right as against the authority that makes the law on which the right depends." Kawananakoa v. Polyblank, 205 U.S. 349, 353 (1907). The prevailing American philosophy, however, is that the people and not the state are supreme. See Comment, $A$ Definition and Explanation of the Sovereignty in the Polity of the United States, 3 Houston L. REv. 368 (1966). Today, the doctrine of sovereign immunity rests primarily on the policy of non-interference with government activities. See Land v. Dollar, 330 U.S. 731, 738 (1947). See generally Borchard, Governmental Responsibility in Tort, 36 Yale L.J. 757 (1927); Pugh, Historical Approach to the Doctrine of Sovereign Immunity, 13 LA. L. Rev. 476 (1953). 


\section{government, ${ }^{17}$ Congress has on a number of occasions expressly}

1 Because the doctrine of sovereign immunity applies only to suits against the United States, litigants have sought to avoid its application by attempting to secure relief against government officials, rather than naming the United States as defendant. Support for this strategy was found in the Supreme Court holding that only when the sovereign was a record party defendant would the jurisdictional bar of its immunity be invoked. See Osborn v. Bank of the United States, 22 U.S. (9 Wheat.) 738 (1824). This test, however, was abandoned four years later when it became apparent in a suit against an official that the judgment would actually operate against the government. See Governor of Georgia v. Madrazo, 26 U.S. (1 Pet.) 110 (1828). Thereafter, courts have stressed the effect of the relief sought in determining whether a suit, though nominally against a federal official, is in fact against the United States. Thus, jurisdiction has been denied when the net effect of the judgment would be (1) to compel performance of a contract as against the Government, see Ove Gustavsson Contracting Co. v. Floete, 278 F.2d 912 (2d Cir. 1960); (2) to compel the Government to part with property the title to which is admittedly in the Government, see Hawaii v. Gordon, 373 U.S. 57 (1963); and (3) to collect money from the public treasury, directly or indirectly, see Manhattan-Bronx Postal Union v. Gronouski, 350 F.2d 451, 455 (1965). See generally Note, 65 HARV. L. REv. 466 (1952); Block, Suits Against Government Officers and the Sovereign Immunity Doctrine, 59 HARv. L. REV. 1060 (1946).

In addition, an official cannot be held personally liable if his action is authorized. See Cary v. Curtis, 44 U.S. (3 How.) 236 (1845). If, however, an officer's actions are without statutory or constitutional authority, an action against him usually will not be barred by sovereign immunity unless an issue within any of the above three groups is also involved. See Larson v. Domestic \& Foreign Commerce Corp., 337 U.S. 682 (1949) (action seeking specific performance of contract rcquiring conveyance of government property); Note, 65 HARV. L. REv. 466, 469-70 (1952). This test, based on a theory of agency, implies that when a government official acts outside the scope of his constitutional or statutory authority, his action is taken in an individual rather than an official capacity and is enjoinable as such. Compare Malone v. Bowdoin, 369 U.S. 643 (1962) (action of ejectment against official held to be against Government in absence of claim the defendant excecded his authority) with Joint Anti-Facist Refugee Comm. v. McGrath, 341 U.S. 123 (195 I) (official's act treated as unauthorized since it was alleged to be purely arbitrary). See generally Rabinowitz v. Kennedy, 376 U.S. 605 (1964) (suit for a declaratory judgment); Udall v. Littell, 338 F.2d 537 (D.C. Cir. 1964), 366 F.2d 668 (D.C. Cir. 1966), cert. denied, 385 U.S. 1007 (1967); Note, Sovereign Immunity and Specific Relief Against Federal Officers, 55 Colum. L. REv. 73 (1955).

Because the revenue officials were apparently acting within their statutory authority, King could not expect to avoid the defense of sovereign immunity by instituting action against them personally. It is also doubtful that King could have succeeded by bringing action against the Under-Secretary of the Army for relief in the nature of mandamus, which will lie only when a statute leaves the officer with no choice of action. Had an action in the nature of mandamus been available, suit could have been brought in district court under 28 U.S.C. $\$ 1361$ (1964), a new provision granting mandamus jurisdiction to all district courts. For details see D. SCHWARTZ \& S. JACOBY, Government Litigation-CASES AND Notes 58I-89 (1963); Jacoby, The Effect of Recent Changes in the Law of "Nonstatutory" Judicial Review, 53 GEo. L.J. 19 (1964).

The Under-Secretary possesses considerable discretion in determining an officers' physical fitness since medical judgments are to some extent inherently arbitrary. Offering some guidelines, 10 U.S.C. $§ 1204$ (1964) provides that the Secretary's decision is to determine that, "(1) based upon accepted medical principles, the disability is of a permanent nature; (2) the disability is the proximate result of performing active duty or inactive-duty training; (3) the disability is not the result of the member's intentional misconduct or willful neglect, and was not incurred during a period of unauthorized absence. . . " However, the Seeretary's decision is considercd to be one of fact and the only basis for an injunction would be that he has acted 
waived sovereign immunity by legislative fiat. ${ }^{18}$ The initial step was taken in 1855 with the creation of the Court of Claims ${ }^{19}$ to hear suits against the United States founded upon any act of Congress, any regulation of the Executive Department, or any express or implied contract with the United States, and to make periodic reports of its findings to Congress. ${ }^{20}$ Under the Act of 1863 , the court was given the power to render final judgments on these claims. ${ }^{21}$ Finally, in 1887 the Tucker Act, ${ }^{22}$ while incorporating these features from the previous two Acts, extended the court's jurisdiction to claims founded upon the United States Constitution and to claims for liquidated or unliquidated damages in cases not sounding in tort, ${ }^{23}$ and granted the district and circuit courts limited concurrent jurisdiction for claims

arbitrarily. Since this is what King alleged in his suit against the United States, it seems that he might have avoided problems by seeking an injunction or a declaratory judgment against the Under-Secretary based on a claim that he had acted arbitrarily and thus beyond his fact-finding statutory authority. Apparently, this route was not taken because of King's desire for a refund. See cases cited in note 11 supra and Chambers v. Robertson, 183 F.2d 144 (D.C. Cir. 1950), rev'd on other grounds, 341 U.S. 37 (1951) (statutory language of what constitucs "service records" found to be clear and unambiguous). See generally Developments in the Law-Remedies Against the United States and Its Officials, 70 HARv. L. REv. 827, 831-64 (1957).

${ }^{18}$ See 28 U.S.C. $\$ \S 1346 \& 1491$ (1964) (Tucker Act); id. $\S \S 1346(b), 1402(b), 1504,2110$, 2410(b), 2411(b), 2412(c), \& 2671-80 (tort claims); id. $\S 1347$ (partition where U.S. is a tenant); id. $\$ \S 1353$ \& 1505 (1ndian claims); id. $\$ \S 1495$ \& 2513 (damages for erroneous conviction); ld. $\S 1498$ (patent infringement); id. $\S 1499$ (government contractor's action for liquidatcd damages); 46 U.S.C. $\S \S 741-52$ \& 781-90 (1964).

${ }^{19}$ For a detailed history of the Court of Claims see Glidden v. Zdanok, 370 U.S. 530 (1962); Pocono Pines Assembly Hotels Co. v. United States, 73 Ct. Cl. 447, 466-92, motion to file for writ of mandamus and/or prohibition denied, 285 U.S. 526 (1932); Hoyt, Legislative History', I West CT. Cl. Digest at xiii (1950); Richardson, History, Jurisdiction, and Practice of the Court of Claims of the United States, $17 \mathrm{Ct}$. Cl. 3 (1882). For a discussion of various aspects of Court of Claims litigation see Brenner, Judicial Review by Money Judgment in the Court of Claims, 21 FED. B.J. 179 (1961); Madden, Aspects of Litigation in the Court of Claims, 86 WASH. L. ReP. 566 (1958); A Symposium-The United States Court of Claims, 55 Geo. L.J. 393-655 (1967).

${ }^{20}$ Act of Feb. 24, 1855, ch. 122, 10 Stat. 612. 1nitially, the court was "no more than a commission exercising powers of investigation with the single right of stating its conclusions to Congress," and "its conclusions and opinions [were] no more than recommendations to Congress." Pocono Pines Hotels Co. v. United States, $73 \mathrm{Ct}$. Cl. 447, 466-67, motion to file for writ of mandamus and/or prohibition denied, 285 U.S. 526 (1932).

${ }^{21}$ Act of March 3, 1863, ch.92, 12 Stat. 765.

${ }^{22}$ Ch. 359, 24 Stat. 505 (1887) (codified at 28 U.S.C. $\$ \$ 1346 \& 1491$ (1964)).

${ }^{23} 28$ U.S.C. $\$ 1491$ (1964), which is derived from the Tucker Act, provides: "The Court of Claims shall have jurisdiction to render judgment upon any claim against the United States founded upon the Constitution, or an Act of Congress, or any regulation of an executive department, or upon any express or implied contract with the United States, or for liquidated or unliquidated damages in cases not sounding in tort." 
not exceeding $\$ 10,000 .{ }^{24}$ As with the previous act, however, there was no provision for satisfaction or enforcement of judicial decrees other than money judgments..$^{25}$ For this reason, the Court of Claim's jurisdiction has traditionally been construed as limited to suits against the government for money judgments. ${ }^{26}$

This view as to the court's jurisdiction can be traced directly to the Supreme Court's decisions in United States $v$. Alire ${ }^{27}$ and United States $v$. Jones. ${ }^{28}$ Both suits were instituted in the Court of Claims requesting specific performance to compel the issue and delivery of a patent for public land, and in both, the Supreme Court held that the Court of Claims was without power to give equitable relief by specific performance. ${ }^{29}$ In construing the Act of 1863, the Alire opinion emphasized that the provisions governing Court of Claims procedure made allowance only for money awards. Thus, it was noted that section five of that Act, providing for Supreme Court review of Court of Claims judgments, authorized review only "wherein the amount in controversy exceeded three thousand dollars." 30 It was further pointed out that section seven, relating to execution of judgments, established procedure only for the recovery of "sum[s]." ${ }^{31}$ On the reasoning that

\footnotetext{
${ }^{24}$ At first the district courts could only hear actions for $\$ 1,000$ or less and the circuit courts actions for between $\$ 1,000$ and $\$ 10,000$. Act of March 3, 1887, ch. 359, \$2, 24 Stat. 505. Now cases involving up to $\$ 10,000$ may be tried in the district courts. 28 U.S.C. $\S 1346$ (a)(2) (1964). Actions which could otherwise be brought in the federal district courts under the Tucker Act must be maintained in the Court of Claims if the claim is for more than $\$ 10,000$. See Schultz, Proposed Changes in Government Contract Disputes Settlement: The Legislative Battle Over the Wunderlich Case, 67 HARv. L. Rev. 217, 250 (1953) (proposal that limit be raised at least to $\$ 100,000$ in view of intervening economic changes). Compare 28 U.S.C. $\$ 1346(a)(2)(1964)$ with id. $\$ 1491$.

${ }^{25}$ See note 31 infra.

${ }^{26}$ The court has limited equitable powers, however. See notes 110 \& 111 infra and accompanying text.

2773 U.S. (6 Wall.) 573 (1867).

28131 U.S. 1 (1889).

${ }^{29}$ Accord, Almour v. Pace, 193 F.2d 699 (D.C. Cir. 1951); Gaines v. United States, 13I F. Supp. 925 (Ct. Cl. 1955) (court held to be without jurisdiction to reinstate discharged employee and grant him classified civil-service status); Ford Bros. \& Co.v. Eddington Distilling Co., $30 \mathrm{~F}$. Supp. 213 (M.D. Pa. 1939); Kelly v. United States, 133 Ct. Cl. 571 (1956) (suit to reassign civil service employee to higher GS grade dismissed as being beyond court's money-judgment jurisdiction); Hart v. United States, $91 \mathrm{Ct}$. Cl. 308 (1940) (restoration of officer held not within court's jurisdiction).

${ }^{30}$ The Act of March 3,1863, ch. 92, $\S 5,12$ Stat. 766 provides as follows: "That either party may appeal to the Supreme Court of the United States from any final judgment or decree which may hereafter be rendered in any case by said court wherein the amount in controversy exceeds three thousand dollars . . . . This dollar limitation on Supreme Court review was not dropped until the passage of the Act of February 13, 1925. ch. 229, § 3,43 Stat. 936, 939.

"The Act of March 3, 1863, ch. 92, $\$ 7,12$ Stat. 765, 766 provides as follows: "That in all
} 
the "power given to render a judgment necessarily restrains the general terms" of the jurisdictional grant, it was concluded that the statute "confines the subject-matter to cases in which the petitioner sets up a moneyed demand as due from the government." 32 Undertaking the same type of analysis, the Court in Jones found that under the Tucker Act, "jurisdiction as to subject matter" of both the Court of Claims and the district and circuit courts was "properly applicable only to a money claim." 33 Perhaps a more meaningful explanation, however, was articulated in the Court's concluding statement:

[W]e should have been somewhat surprised to find that the administration of vast public interests, like that of the publie lands, which belong so appropriately to the political department, had been cast upon the courts-which it surely would have been, if such a wide door had been opened for suing the government to obtain patents and establish land claims......$^{34}$

While the technical grounding of these decisions was the absence of procedures for enforcement of judgments for specific relief or, indeed, for any relief other than a money judgment, the concluding remarks in Jones suggest two underlying considerations. In the absence of explicit congressional authorization, the Supreme Court seems to have been uneasy over the possibility, on the one hand, of a flood of claims against the government ${ }^{35}$ and, on the other hand, of injecting itself into the operations of the executive department by direct coercion of federal officials. ${ }^{36}$

Whether the Supreme Court in Jones did in fact distinguish relief from jurisdiction when it defined "jursdiction as to subject matter" strictly in terms of "money claims" can only be a matter of speculation. It is clear, however, that the concept of money-judgment jurisdiction, which firmly entrenched itself in subsequent cases, was premised on an equation of remedy and jurisdiction, ${ }^{37}$ or, more

cases of final judgments by said court, or on appeal by the said Supreme Court where the same shall be affirmed in favor of the claimant, the sum due thereby shall be paid out of any general appropriation made by law for the payment and satisfaction of private claims . . . "This section was not repealed by the Tucker Act.

${ }^{32}$ United States v. Alire, 73 U.S. (6 Wall.) 573, 576 (1867).

${ }^{33}$ United States v. Jones, 131 U.S. 1, 19 (1889).

${ }^{34} I d$. (emphasis added).

${ }^{35}$ An avalanch of claims against the governments has apparently not occurred in Europe where the governments commonly accept financial responsibility for their acts. See note 16 supra.

${ }^{36}$ See text accompanying notes 70-71 infra.

${ }^{37}$ The equation of remedy and jurisdiction has occurred in other areas. In New Jersey, where 
specifically, the necessity of a remedy for the existence of jurisdiction. An unarticulated, corollary proposition was that a court's jurisdiction would probably expand with the addition of a remedy. It was not surprising, therefore, that when declaratory relief became available in "courts of the United States" 38 in 1934, the first court to consider its applicability to Tucker Act litigation suggested that jurisdiction would be expanded. Thus, in Twin Cities Properties, Inc. v. United States ${ }^{39}$ plaintiff realty company brought an action under the Tucker Act in the Court of Claims to declare that a certain lease agreement was binding on the United States, and that plaintiff was entitled to receive rent thereunder. In dismissing the petition the Court of Claims found that the requisite jurisdiction was not provided for by the Declaratory Judgment Act, and that declaratory proceedings were wholly alien to the court. It was reasoned that "[i]f Congress had intended to extend the scope of this court's jurisdiction and subject the United States to the declaratory judgment act, . . . express language would have been used to do so . . . ."40

Conceivably, the court might have contended that an expansion of Tucker Act jurisdiction to allow declaratory relief would violate Congress' express intent that the Declaratory Judgment Act apply only to cases "within its jurisdiction." Instead, only cursory judicial notice was taken of legislative intent. However, by requiring a totally unambiguous congressional statement vesting the Court of Claims with authority to grant declaratory relief, the decision affirmed the reluctance initially demonstrated in Jones to allow suits against the United States in the absence of express statutory authorization."

the administration of justice was at one time divided between courts of law and equity, jurisdiction was denied in equity courts when the dispute was essentially a legal question. See. e.g.. Wight v. Board of Educ., 99 N.J. Eq. 843, 133 A. 387 (1926). In addition, courts have refused jurisdiction where the dispute was of a political nature, saying that the remedy lies in Congress and the people rather than in the courts. Colegrove v. Green, 328 U.S. 549 (1946). In spite of the full faith and credit clause, courts need not enforce equitable decrees of sister states where the forum lacks remedial machinery. For example, in Consolidated Copper Mines Corp. v. Nevada Consolidated Copper Co., 127 Misc. 71, 215 N.Y.S. 265 (1926), an action was brought in New York under a Nevada statute providing for treble damages for trespass upon ore mines if done in bad faith, and provided that the judge could order a survey of the land and place a lien upon it. In dismissing the suit it was held that the Nevada statute was a special statutory remedy enforceable only in Nevada. See also Slater v. Mexican Nat'l R.R., 194 U.S. 120 (1904); Fall v. Eastin, 75 Neb. 104, 113 N.W. 175 (1907).

"This term was not defined by the Deelaratory Judgment Act of 1934. See J. Moore, Federal Practice $\S 57.02(4)$ (1966).

${ }^{39} 81 \mathrm{Ct}$. Cl. 655 (1935).

+o ld. at 658 .

"See note 90 infra. 
Here, the Twin Cities court found support in two cases standing for the positions that a presumption exists against the suability of the federal government which must be overcome by statute, ${ }^{42}$ and that a statutory waiver of sovereign immunity is to be strictly construed..$^{43}$ It seems apparent, therefore, that the court's original hostility to declaratory relief emanated from the doctrine of sovereign immunity.

Thus, the concept of money-judgment jurisdiction remained unaffected by the passage of the Declaratory Judgment Act, and in subsequent cases the Court of Claims invariably held that it was without power to render declaratory judgments.4 The same was generally true of the district courts and courts of appeals in their limited concurrent jurisdiction under the Tucker Act, ${ }^{45}$ even though, concomitantly, they granted declaratory relief under other special jurisdictional statutes such as the Suits in Admiralty $\mathrm{Act}^{46}$ and the

42 Eastern Transp. Co. v. United States, 272 U.S. 675, 686 (1927) (suit to determine whether Suits in Admiralty Act would permit libellant to proceed against Government where proceeding in rem was unavailable).

${ }^{43}$ United States v. Michel, 282 U.S. 656, 660 (1931) (taxpayer's claim filed beyond the statutory period). For a later case tending to support tbis view see United States v. Sherwood, 312 U.S. 584 (1941).

${ }^{44}$ Many of these cases are cited in notes 47-50 infra. While the Supreme Court has never considered application of the Declaratory Judgment Act to Tucker Act litigation, it has in several decisions since 1934 had occasion to repeat the oft-noted statement as to the court's "money damage" jurisdiction. See Glidden Co. v. Zdanok, 370 U.S. 530,557 (1962); United States v. Jones, 336 U.S. 641,670 (1949).

4s The Declaratory Judgment Act clearly applies to the district courts and courts of appeals; therefore it might seem that there would be no question as to their power to grant declaratory relief in any type of case. At least one reason for their holding to the contrary is that their power to grant relief under the Tucker Act has been said to be no greater or less than that possessed by the Court of Claims over the same kind of casc. See United States v. Sherwood, 312 U.S. 584, 591 (1941) (Federal Rules of Civil Procedurc held not to affect district court's Tucker Act jurisdiction so as to permit joinder of private defendants).

${ }^{46}$ Suits in Admiralty Act, 46 U.S.C. $\$ \S 741-52$ (1964). In American-Foreign S.S. Corp. v. United States, 291 F.2d 598, 604 (2d Cir.), cert. denied, 368 U.S. 895 (1961), the court permitted an action for declaratory relief stating: "The Suits in Admiralty Act does not specifically sanction declaratory relief against the United States. However, nowhere in that statute is there any indication that the significant reforms later introduced by the Declaratory Judgment Act ... should not be applicable to admiralty courts and to libels in admiralty against the government. Furthermore, the wording of the Declaratory Judgment Act makes it broadly applicable to 'any court of the United States' whicb would include, presumably, the admiralty courts." See also Luckenbach S.S. Co. v. United States, 312 F.2d 545 (2d Cir. 1963); American President Lines v. United States, 162 F. Supp. 732, 739 (D. Del. 1958), affd per curiam, 265 F.2d 552 (3d Cir. 1959). Declaratory relief in admiralty suits was provided by the 1961 amendment to the Rules of Practice in Admiralty and Maritime Cases. See Luckenbach S.S. Co. v. United States, 292 F.2d 913, 917 n.6 (Ct. Cl. 1961): "The Declaratory Judgment Act ... is applicable in 'any court of the United States,' and no exception is made for the admiralty courts." 
Federal Tort Claims Act. ${ }^{47}$ Most of the decisions, however, failed to represent clear holdings that the Declaratory Judgment Act did not apply to Tucker Act litigation. ${ }^{48} \mathrm{~A}$ number of suits requesting declaratory relief were turned down either because no relief of any

${ }^{47}$ Federal I ort Claims Act, ch. 753, 60 Stat. 842 (1946) (codified in scattered sections of 28 U.S.C.). Pennsylvania R. R. v. United States, 111 F. Supp. 80, 86 (D.N.J. 1953), concerned a complicated situation involving the Tort Claims Act, where the plaintiff sought a declaratory judgment to determine the various rights of the many parties. In allowing such a proceeding, the court viewed it as merely a "procedural" step in the development of a "money claim." But see Aktiebolaget Bofors v. United States, 93 F. Supp. 134 (D.D.C. 1950) (semble), aff d on other grounds, 194 F.2d 145 (D.C. Cir. 195 I). It is important that the Tort Claims Act is similar to the Tucker Act in that it gives the district courts exclusive jurisiction of "civil actions on claims against the United States, for money damages." 28 U.S.C. $\$ 1346(\mathrm{~b})$ (1964) (emphasis added).

Another example is the Trading With the Enemy Act, 50 U.S.C. App. $\$$ 9(a) (1964). In Brownell v. Ketcham Wire \& Mfg. Co., 211 F.2d 121, 128 (9th Cir. 1954), a licensee brought an action seeking a deelaratory judgment that a certain licensing agreement was enforceable and an injunction to prevent the government from granting further licenses to third parties. In holding the agreement legal, the court reasoned that while "[i]t is true that the Declaratory Judgment Act . . . is not a consent of the United States to be sued, and merely grants an additional remedy in cases where jurisdiction already exists," jurisdiction of the parties and subject matter was clearly present.

There is also the National Service Life Insurance Act, $38^{\circ}$ U.S.C. $\$ \S 701-25$ (1964). In Unger v. United States, 79 F. Supp. 281, 283-84 (E.D. Ill. 1948), plaintiff sought a declaration of his right to insurance. In granting jurisdiction, the court reasoned that if the Act authorizes suit against the Government, then it is "only reasonable to hold that congress [sic] intended to consent to the use of Declaratory [sic] judgment procedure."

Finally, certain relevant action has taken place regarding 28 U.S.C. $\S 2410$ (1964). In Pettengill v. United States, 205 F. Supp. 10, 12 (D. Vt. 1962) (alternative holding), the court permitted an action for a declaratory judgment seeking to free certain property owned by plaintiffs from tax liens of the goverrment. In Soniz v. United States, 221 F. Supp. 762, 764 (D.N.J. 1963), resort to the Declaratory Judgment Act was held unnecessary in a section 2410 suit since an action to quiet title was said to be, in essence, a declaratory action. See also Falik v. United States, 343 F.2d 38 (2d Cir. 1965). But in Zito v. Tesoriero, 239 F. Supp. 354 (E.D.N.Y. 1965), an action to declare plaintiff the rightful owner of certain property, the declaratory judgment remedy was denied on the grounds that the government had not waived sovereign immunity.

${ }^{48}$ See Wells v. United States, 280 F.2d 275 (9th Cir. 1960) (dictum); Cobb v. United States, 240 F. Supp. 574, 577-79 (W.D. Ark. 1965) (dictum); Lowe v. United States, 37 F. Supp. 817 (D.N.J. 1941) (dictum); Shaw v. United States, 357 F.2d 949, 963 (Ct. Cl. 1966) (limiting a money recovery to the amount owing at the date of judgment). See also Severein v. United States, 99 Ct. Cl. 435, 443 (1943) (alternative holding) (Tucker Act does not supply jurisdiction to grant nominal damages). In Severein the court relied on the "Gold Clause" case, Nortz v. United States, 294 U.S. 317, 327 (1935). Accord, Perry v. United States, 294 U.S. 330, 335 (1935). Neither Perry nor Nortz are meaningful precedent to the issue here. In each case the Supreme Court found that the plaintiff's claim was inevitably for nominal damages only, and that the Court of Claims had "no authority to entertain an action for nominal damages." Id. at 355. It is clear in the context of the decision, however, that this statement simply indicates that the judicial authority of the Court of Claims, as of all federal courts, is confined to real cases and controversies. 
kind cou [d be granted ${ }^{+y}$ or because the restrictions on other forms of available relief would be improperly circumvented. ${ }^{50}$

4 Situations in which declaratory relief has been denied on grounds of a court's lack of authority to grant any relief are illustrated by the following examples:

(i) Where the Government has not consented to be sued on a particular causc of action. See Savorgnan v. United States, 17I F.2d 155, 159 (7th Cir. 1948), aff'd on other grounds, 338 U.S. 491 (1950) (action to declare plaintiff an American citizen); Bell v. United States, 203 F. Supp. 371,374 (W.D. Wis. 1962) (alternative holding) (action by rcleased prisoner for a declaration discharging him from all parole supervision); Birge v. United States, 111 F. Supp. 685 (W.D. Okla. 1953) (suit to declare insured's right to have a disability-income clause added to policy); Schilling v. United States, 101 F. Supp. 525 (E.D. Mich. 1951) (no provision for judicial review); Commers v. United States, 66 F. Supp. 943, 949-50 (D. Mont. 1946) (alternative holding), aff $d$ per curiam, 159 F.2d 248 (9th Cir.), cert. denied, 331 U.S. 807 (1947) (action by disabled serviceman to declare his induction a taking of property thereby entitling him to compensation); Rolls-Royce Ltd. v. United States, 364 F.2d 415, $419-20$ (Ct. Cl. 1966) (intervenor's counterclaim against government for declaratory judgment that plaintiff's patent was invalid).

(ii) Where the matter is non-justiciable because committed to cxclusivc agency discretion. See Love v. United States, 108 F.2d 43, 50 (8th Cir. 1939), cert. denied, 309 U.S. 673 (1940) (plaintiff seeking declaration that he was entitled to a certain type of government job); Wohl Shoe v. Wirtz, 246 F. Supp. 821 (E.D. Mo. 1965) (action to declare cmployers' excmption of liability under Fair Labor Standards Act); Ncw York Technical Institute of Maryland, Inc. v. Limburg, 87 F. Supp. 308, 3 I I-13 (D. Md. 1949) (altcrnative holding) (suit to declare vctcran not subject to certain cost data regulation in computing tuition grant).

(iii) Where the cause of action is invalid because not based on any constitutional or statutory right. See Drill v. United States, 157 Ct. Cl. 945 (1962), cert. denied, 372 U.S. 912 (1963) (action to declare veteran's right to federal cmployment).

(iv) Where there is no jurisdiction over the subject matter except in the Court of Claims. Sec Ove Gustavsson Contracting Co. v. Floete, 278 F.2d 912 (2d Cir.), cert. denied, 364 U.S. 894 (1960) (amount in contract suit cxceeded \$10,000); Powers v. United States, 218 F.2d 828 (7th Cir. 1954); Richfield Oil Corp. v. United States, 207 F.2d 864, 868, 871-72 (9th Cir. 1953) (alternative holding); Aktiebolaget Bofors v. United States, 194 F.2d 145, 150 (D.C. Cir. 195I).

${ }^{30}$ The following examples illustrate situations in which declaratory relief has been denied in order to prevent frustration of another specific remedial scheme:

(i) Rather than relying on the specific cxclusion of suits "with respect to federal taxes" in the Declaratory Judgment Act, some courts have denied declaratory relief, instead, on the ground it would subvert Tax Court procedures. See Balistrieri v. United States, 303 F.2d 617 (7th Cir. 1962); Zito v. Tesoriero, 239 F. Supp. 354 (E.D.N.Y. 1965).

(ii) Since habeas corpus is the accepted remedy for prisoners, courts arc reluctant to allow prisoners to by-pass this type of proceeding with a declaratory judgment action. Where a writ of habeas corpus is available, the court might avoid the problem by considering the petition for a declaratory judgment as being one for a writ of habeas corpus. On the other hand, declaratory relief has been denied wherc habeas corpus proceedings wcrc unavailable, the court saying either that the petition was premature or that the petitioner failed to exhaust his administrativc remedies. For example, in 1nnes v. Hiatt, 57 F. Supp. 17 (M.D. Pa. 1944), the court, denying a prisoner's action for a declaration as to the proper manner of computing the length of his sentence, reasoned that even if the petition had been considered as being an application for a writ of habeas corpus, it would have been premature inasmuch as the petitioncr had not served his full sentence less "good time" deductions. See Gibson v. United States, 161 F.2d 973 (6th Cir. 1947) (prisoner seeking by declaratory judgment adjudication of basis of deduction of time for good 


\section{Allowance of Declaratory Relief}

While many cases are clearly in line with Twin Cities, ${ }^{51}$ two decisions in particular suggested that the Court of Claims might be ready to re-examine its position. In Raydist Navigation Corp. $v$. United States, ${ }^{52}$ a federal district court for the first time extended declaratory relief to Tucker Act litigation on the grounds that, while the Declaratory Judgment Act granted merely an additional remedy rather than a waiver of sovereign immunity, the Government had already given its consent to be sued under the Tucker Act. Implicit in the Raydist decision was a rejection of the rationale in $T$ win Cities that permission to render declaratory judgments in Tucker Act

conduct from his sentence); United States v. Rollnick, 33 F. Supp. 863, 866-67 (M.D. Pa. 1940) (plaintiff suing to correct a sentence imposed by another court).

(iii) Litigants refusing to follow statutory procedures cannot obtain declaratory relief on a theory that such refusal constitutes an "actual controversy" under the Declaratory Judgment Act. See Isner v. ICC, 90 F. Supp. 361,366 (E.D. Mich. 1950).

(iv) Where the recommendation of an agency is required for the granting of certain benefits, and no statutory rules have becn laid down to guide such recommendations, it has been held that a judicial probe of the agency's reasoning " would amount to a clear invasion of the legislative and executive domains." Gibney v. United States, 146 F. Supp. I35, 140 (S.D. Cal. 1956), quoting United States v. George S. Bush \& Co., 310 U.S. 371, 380 (1940). See also Wells v. United States, 280 F.2d 275 (9th Cir. 1960).

s1 In United States Rubber Co. v. United States, 160 F. Supp. 492, 500 (Ct. Cl. 1958), plaintiff sought a declaration of its right to recover excess unemployment compensation taxes accruing in future years where they were traceable to a certain war contract. In Yeskel v. United States, 31 F. Supp. 956, 957-58 (D.N.J. 1940) (alternative holding), plaintiff sought to determine by a declaratory judgment its rights in a government contract so as to establish a defense to a suit the government might bring against him. And in Prentiss v. United States, 115 Ct. Cl. 78 (1949), an active Army officer sought a declaration of his right to retirement pay under the Civil Service Retirement Act. In all three cases, declaratory relief was denied on the grounds that the court's jurisdiction was limited to suits for money judgment or that the Declaratory Judgment Act did not apply to Tucker Act litigation. See Clay v. United States, 210 F.2d 686 (D.C. Cir. 1953), cert. denied, 347 U.S. 927 (1954) (suit under Tucker Act seeking judgment declaring void an assignment of certain letters patent held beyond court's subjeetmatter jurisdiction); Di Battista v. Swing, 135 F. Supp. 938 (D. Md. 1955) (suit to declare that alien had not breached his immigration bond denied in absence of money-judgment claim).

32 144 F. Supp. 503 (E.D. Va. 1956). The proceeding arose out of the contentions of the United States that Raydist had charged inflated costs under a completed cost-plus contract with the United States. As all payments under that contract had been completed, it withheld a portion of the alleged overpayments from funds due under a later contract with Raydist, and apparently threatened to continue this practice. Thereafter, Raydist sought and obtained declaratory relief. With citation to the decisions in Pennsylvania R. R. v. United States, 111 F. Supp. 80 (D.N.J. 1953), and Brownell v. Ketcham Wire \& Mfg. Co., 211 F.2d 121 (9th Cir. 1954), inter alia, the court explained: "While it is undoubtedly true that the Declaratory Judgment Act . . . is not a consent of the United States to be sued, and merely grants an additional remedy in cases where jurisdiction already exists, it follows that where, as here, the United States has given its consent to be sued under the Tucker Act . . . and the unusual nature of the circumstances are such as to justify an initial determination of the rights of the parties, a proceeding by way of declaratory judgment is decmed appropriate." 144 F. Supp. at 505. 
proceedings would constitute an additional consent by the Government to be sued. Although Raydist has essentially stood alone for this proposition, in 1967 the Court of Claims expressly reserved consideration of its jurisdiction under the Declaratory Judgment Act. ${ }^{53}$ Thus, the court's reversal in King was not altogether unexpected.

Jurisdiction Analysis. Instead of advocating a strict construction of statutory language, which was the basis of the court's holding in Twin Cities, the Government chose a slightly different approach in King. It reasoned that the Court of Claims was restricted to rendering money judgments; that its jurisdiction would be extended by the availability of declaratory relief; that the Declaratory Judgment Act did not grant additional jurisdiction to any court; and that, therefore, the Act did not apply to the Court of Claims. ${ }^{54}$ In rebutting this argument, it was critically important to demonstrate that the addition of declaratory relief to the court's remedial powers would not necessarily extend its jurisdiction. For this proposition, the court relied on Skelly Oil Co. v. Phillips Petroleum Co.,5s in which the Supreme Court succinctly defined the purpose of Congress in passing the Declaratory Judgment Act:

Congress enlarged the range of remedies available in the federal courts but did not extend their jurisdiction ... [and] jurisdiction means the kind of issues which give right of entrance to federal courts. Jurisdiction in this sense was not altered by the Declaratory Judgment Act. ${ }^{56}$

The court also recognized that under the Tucker Act a claim must be founded upon "the Constitution, a statute, a regulation, or contract, or must be nontortious in character," 57 and, to satisfy Supreme Court precedent, must in some way demand the payment of money. 1t was then concluded that declaratory relief would not extend the court's jurisdiction beyond this category of claims because, by requiring the action to be directed toward a money judgment, it would merely enable claimants to initiate proceedings at an earlier stage, even prior to the accrual of damages.

\footnotetext{
${ }^{33}$ Eastport S.S. Corp. v. United States, 372 F.2d 1002, 1007 n.5 (Ct. Cl. 1967).

"Defendant's Response To Plaintiffs Brief on The Applicability Of The Declaratory Judgment Act To This Court And To This Case, July 19, 1967, at 3-6.

ss 339 U.S. 667 (1950).

${ }^{56} I d$. at 671 (emphasis added).

${ }^{37} 390$ F.2d at 908.
} 
As an indication of the underlying significance of the court's holding, claimants in contractual disputes, for example, need not delay action until the dispute has completely matured. ${ }^{58}$ In those instances where a government contract is reformed to a party's disadvantage, he should be able to bring suit immediately, whereas previously he was barred from instituting proceedings until money on the contract became due. ${ }^{59}$ Similarly, in civil and military cases, a claimant should be entitled to bring an action prior to the time when such payment becomes due, provided administrative remedies have been exhausted ${ }^{60}$ and other jurisdictional requisites are present. It would appear, therefore, that the availability of declaratory relief could be viewed as similar to an affirmation of ripeness in suits heretofore said to be premature..$^{61}$

The court's reasoning may at first appear erroneous in that, while it implies that jurisdiction might exist regardless of whether the Declaratory Judgment Act was in existence, it is apparent that new legal interests are afforded protection. This confusion stems from the courts' use of the term jurisdiction in at least two different senses ${ }^{62}$ without distinguishing its respective meanings. ${ }^{63}$ On the one hand,

\footnotetext{
s8 For a discussion of the availability of declaratory relief when the plaintiff has a matured cause of action see Note, Declaratory Judgment and Matured Causes of Action, 53 Colum. L. REv. 1130 (1953).

"See Oceanic S.S. Co. v. United States, 165 Ct. Cl. 217 (1964). In operating-differential subsidy contracts, a matured claim does not arise until the completion of the annual accounting. This can involve delays of prodigious proportions.

${ }^{\infty}$ Few rules are better settled than the requirement that the plaintiff must exhaust his administrative remedies before he can file his petition in the Court of Claims. See, e.g., United States v. Anthony Grace \& Sons, Inc., 384 U.S. 424, 429-30 (1966). Most of the cases coming to the Court of Claims have becn sifted through administrative proceedings. Jaffe, Remand Powers of the Court of Claims, 56 GEo. L.J. 444, 453 (1967). Where the administrative process has not been exhausted, declaratory relief is usually denied. See Macauley v. Waterman S.S. Corp., 327 U.S. $540,544-45$ (1946). However, if there is a showing of inadequacy of the administrative remedy and of impending harm, the agency can sometimes be circumvented. See Aircraft \& Diesel Equip. Corp. v. Hirsch, 331 U.S. 752, 773-74 (1947); Order of Railway Conductors of Am. v. Swan, 329 U.S. 520, 524-25 (1947). There seems to be no compelling reasons why the same rules should not apply to declaratory relief in Tucker Act litigation.

6) For a discussion of the relationship between ripeness and declaratory relief see $\mathrm{E}$. BORCHARD, DECLARATORY JUDGMENTS 56-7I (2d ed. 194l) [hereinafter cited as BoRCHARD].

62 BORCHARD 232: "It may be conceded that the word 'jurisdiction' is often used ambiguously. It is used (1) in its stricter sense ás judicial authority over subject-matter and parties; and (2) as the privilege and power to grant specific relief in cases within such authority."

${ }^{63} 1$ J. POMeroy, Equity JuRisprudence $\S \S 129-30$ (4th ed. 1918), speaks of jurisdiction in two scnses: (1) "the power residing in such course to determine judicially a given action, controversy, or question presented to it for decision," $i d$. at 153-54; (2) "the power to hear certain kinds and classes of civil causes according to the principles of the method and procecure adopted by the court of chancery. . . ."Id. at 156.
} 
jurisdiction is taken to mean judicial authority to hear and decide cases. ${ }^{64}$ So when the Court of Claims in Twin Cities concluded that declaratory relief would extend its jurisdiction, it was correct in the sense that the Declaratory Judgment Act enabled courts to entertain suits previously barred from their consideration. On the other hand, the term jurisdiction is also used in the more limited sense of judicial authority over subject matter and person. Jurisdiction over the subject matter, meaning the class of cases on which a court has capacity to act, ${ }^{65}$ was not expanded by the Declaratory Judgment Act. ${ }^{66}$ Since the Act itself refers only to subject-matter jurisdiction when its applicability is restricted to cases within a court's jurisdiction, ${ }^{67}$ the Government's argument in King, that the expansion of the court's jurisdiction would do violence to the purpose of that Act, was without merit. While the discussion in King is somewhat misleading because of its failure to distinguish adequately between these two separate usages of the term jurisdiction, it is clearly an overstatement of the court's position to say that its jurisdiction would in no way be expanded by the addition of declaratory relief. In addition, since the concept of money-judgment jurisdiction formulated in Alire and Jones delineates solely the category of claims subject to adjudication under the Tucker Act and is, therefore, an offshoot of the concept of subject-matter jurisdiction, the court was clearly correct in assuming that declaratory relief would not result in its enlargement so long as the claims remained money-related..$^{65}$

\footnotetext{
${ }^{64}$ See Employers Reinsurance Corp. v. Bryant, 299 U.S. 374, 381 n.10 (1936); Acadia Land Co. v. Horuff, 110 F.2d 354, 355 n.l (5th Cir. 1940).

${ }^{65}$ Honea v. Graham, 66 S.W.2d 802, 804 (Tex. Civ. App. 1933) (jurisdiction of subject matter defined as power over "the class of cases to which particular cases belong").

${ }^{66}$ See Southern Pac. Co. v. McAdoo, 82 F.2d 121, 122 (9th Cir. 1936); Putnam v. 1ckes, 78 F.2d 223, 226 (D.C. Cir. 1935); Hary v. United Elec. Coal Co., 8 F. Supp. 655, 656 (E.D. 111. 1934); BORCHARD 233.

${ }^{67} 28$ U.S.C. $\$ 2201$ (1964) permits a court to tender a declaratory judgment only in cases "within its jurisdiction." If jurisdiction were used in its broadest sense, declaratory relief would be available only in those instances where the plaintiff had a matured claim for money or coercive relief. The Act has not been construed in this manner by federal courts. Some state courts have even held that the existence of another adequate remedy precludes declaratory relicf. See, e.g., Burke v. Gardner, 221 Ind. 262, 47 N.E. 148 (1943) (declaration denied where injunction available).

${ }^{68}$ Arguably, the Court's subject-matter jurisdiction would not be affected even in non-moncyrelated cases if the claim against the Government was founded upon the Constitution, a statute, a regulation, a contract, or was non-tortious in character. In other words, these five causes of action under the Tucker Act might be viewed as the class of cases on which the court has capacity to act. The issue is probably moot, however, because the Declaratory Judgment Act has been viewed in a different light. In Putnam v. Ickes, 78 F.2d 223, 226 (D.C. Cir. 1935), the court said: "We think it is clear from any reasonable construction of the acts that the Declaratory
} 
The Specific Relief Problem. Because one of the Supreme Court's principal concerns in Alire and Jones was the direct coercion of public officials, the Court of Claims went to great lengths in demonstrating that "the coercive effect of money and declaratory judgments differs markedly from that of the specific equitable sanctions." 69 When a court issues a decree for specific relief, such as an injunction to prevent an administrative official from engaging in a designated activity, it is directed at a particular administrator and commands obedience. ${ }^{70}$ ln both Jones and Alire, specific relief would have required a court order commanding an affirmative transfer of public lands by a government official, who would thereafter become personally liable in tort for damages upon failure to comply. It can be argued that any judgment, even a declaratory or money judgment, inevitably must have a "coercieve effect," because it constitutes notice to all officials that, unless their conduct is changed, similar awards will be rendered to all subsequent plaintiffs. In consequence, a change in their conduct is demanded ${ }^{71}$ unless they are willing to risk censure or perhaps civil liability. In actuality, the impact of money and declaratory judgments does not stem from fear of personal consequences brought about by court action against delinquent bureaucrats but, rather, from a volitional reaction of responsible government officials who otherwise may risk losing their positions through the elective or appointive process. Declaratory and money

\footnotetext{
Judgment Act has not given the courts jurisdiction . . . if affirmative relief were being sought .... It clearly follows, we think, that in any actual controversy wherein the court otherwise has jurisdiction of the subject-matter and the parties the court has power to determine the rights of the petitioner, although the case may not have developed to a point wherein affirmative relief could be given. This is as far as the act goes." It appears, therefore, that the availability of declaratory relief depends upon the availability of affirmative relief. See Southern Pac. Co. v. McAdoo, 82 F.2d 121, 122 (9th Cir. 1936); Johnston v. Town of Deerfield, 25 F. Supp. 918 (D. Mass.), aff d per curiam, 306 U.S. 621 (1939) (no declaration because there was no basis for equitable relief); Lake Erie Provision Co. v. Moore, 11 F. Supp. 522 (N.D. Ohio 1935) (no declaration because there was no power of injunction to make it effective). BORCHARD, at 23334 , notes two exceptions to this rule: declaration of liens and priorities. In New Jersey, where the courts of law and equity were at one time separate, declaratory relief in an equity court would usually be denied where the question involved was purely legal. Id. at 242-47. All this seems to indicate that deelaratory relief should not be available in non-money-related Tucker Act claims since they are not otherwise reviewable. See note 87 infra.

${ }^{69} 390$ F.2d at 905.

${ }^{70}$ See United States v. Boutwell, 84 U.S. (17 Wall.) 604, 607 (1873) (writ of mandamus commands officer to obey, and in default the costs will fall upon him).

"Once declaratory relief has been obtained, a coercive judgment compelling performance of duty is rarely required because most officials obey court decisions. BORCHARD 876,896 .
} 
judgments against the Government are similar in their restraining force, also, in that both are mere statements of rights ${ }^{72}$ and neither is enforceable in the absence of congressional approval of expenditures. ${ }^{73}$ Finally, one of the motivating forces behind the Declaratory Judgment Act was a desire to obviate the hostility to extensive use of the courts' injunctive powers. ${ }^{74}$ For these reasons, the King court was unconvinced that declaratory relief would conflict with the Alire-Jones rationale.

Congressional Intent. Turning to the issue of Congress' intent in passing the Declaratory Judgment Act of 1934, the opinion in King concluded that the Act's applicability to the Court of Claims was probably not within Congress' express contemplation during either the passage of the Act in 1934 or the revision of the United States Code in 1948. Further, even if a change in the law to include the Court of Claims within the provisions of the Act was intended by Congress in 1948, such an extension having no intended effect on a court's subject-matter jurisdiction, would probably not have been considered controversial. In contrast to Twin Cities, the court in King undertook a thorough analysis of the history of the Act before arriving at this conclusion. Specifically, the court's attention was focused on whether Congress intended to include the Court of Claims within the phrase "courts of the United States," as that phrase was used in the Act to denominate the judicial agencies authorized to grant declaratory relief. This inquiry would seem to have been obviated by the 1948 revision which rephrased the Act to apply to "any court of the United States"75 and explicitly included the Court of Claims within this definition. ${ }^{76}$ Nevertheless, the issue was unsettled due to statements during the revision, for instance, that "great care [was] exercised to make no changes in the existing law which would not meet with substantially unanimous approval." 1 in addition, nothing in the

\footnotetext{
32 BORCHARD 371: "It is not surprising therefore that we find petitions of right expressly seeking declaratory judgments. All actions against the United States under the Tucker Act of I887 and other statutes might well have been so framed." It is an extremcly rare occurrence, however, when the Government refuses to pay a judgment in the Court of Calims.

${ }^{73}$ Judgments of the Court of Claims in excess of $\$ 100,000$ are certified to Congress for appropriation by the Secretary of the Treasury. 28 U.S.C. $\$ 2518$ (1964). Judgments of $\$ 100,000$ or less are paid out of a permanent reolving fund. Act of July 27, 1956, ch. 748, $\S 1302,70$ Stat. 694. In either case, actual payment is made by the General Accounting Office. 28 U.S.C. $\$ 2517($ a).

${ }^{74}$ See S. Rep. No. 1005, 73rd Cong., 2d Sess. 3 (1934).

${ }^{75} 28$ U.S.C. $\$ 2201$ (1964).

${ }^{76}$ Act of June 25, 1948, ch. 646, § 451, 62 Stat. 907 (codified as 28 U.S.C. $\$ 451$ (1964)).

"S. REP. No. 1559, 80th Cong., 2d Sess. 2 (1948).
} 
legislative history of the codification indicated any intention to enlarge the jurisdiction of the Court of Claims, ${ }^{78}$ nor was the court ever mentioned in the reviser's notes. ${ }^{79}$ For these reasons, an inquiry into the intent of Congress was not precluded by the revision.

Despite the period over which the legislation was subject to consideration, the congressional source material is inadequate for a close analysis of the statutory provisions. As noted by the court, however, the chief extra-congressional sponsor of the Act, Professor Borchard, in stating that the Act authorizes declaratory judgments "within the permitted limits"so of the Tucker Act, rebutted any assertion that declaratory relief was to be unavailable in Tucker Act suits. In addition, the frequent references by legislators to the Act's procedural aspects as applicable in "federal courts" suggests that the term was to be given broad, rather than narrow, interpretation. ${ }^{81}$ Finally, numerous analogies were drawn between declaratory judgments and money judgments in the Court of Claims. ${ }^{22}$ On the

\footnotetext{
"See Hearings on H.R. 3214 Before a Subcomm. of Senate Conm. on the Judiciary, 80th Cong., 2d Sess. (1948); Hearings on Revisions of Titles 18 and 28 of the United States Code Before Subcomm. No. I of the House Comm. on the Judiciary, 80th Cong., 1st Sess. (1947); S. REP. No. 1559, 80th Cong., 2d Sess. (1948); H.R. Rep. No. 308, 80th Cong., 1st Sess. (1947). The House and Senate debates are reprinted in U.S. Code Cong. Serv., New Title 28-UNited STATES Code 1986-2040 (1948).

"When the 1934 Act was modified in 1948 as part of the general revision of the Judicial Code, the Revisers noted simply that "changes were made in phraseology." H.R. REP. No. 308, 80th Cong., Ist Sess. A 138 (1947). See also S. Rep. No. 1559, 80th Cong., 2d Sess. 2 (1948). The Reviser's notes make no reference to the Tucker Act or the Court of Claims in the comments on Sections 2201-02 (the Declaratory Judgment Act) and state only that Section 451 was "inserted to make possible a greater simplification in consolidation of the provisions incorporated in this title." 28 U.S.C. $\$ \S 451$ \& 2201-02 (1964). See also Western Pac. R.R. v. Western Pac. R.R., 345 U.S. 247, 254-55 (1953) (Reviser's notes are an authoritative aid for statutory construction).

${ }^{30}$ Borchard 373 (emphasis added): "The introduction of the Federal Declaratory Judgments Act has raised the question whether the position of the United States Government as a defendant has been modified and whether the declaratory judgments could now be obtained against the United States under circumstances outside the terms of the Tucker Act and other statutory authority accepting liability and subjection to suit. The answer clearly is in the negative. Since all judgments against the United States, within the permitted limits, are declaratory in effect, for if successful they merely declare the amount due by the government, a petition would doubtless not be dismissed if it sought a declaratory judgment in such cases."

"See, e.g., S. REP. No. 1005, 73rd Cong., 2d Sess. 3 (1934); 69 CoNG. REc. 1681, 1685, 1686 (1928) (remarks of Representative Celler, Dyer, and Newton); 78 CoNG. REc. 10565 (1934) (remarks of Senator Robinson); Hearings on Legislation Recommended by the Am. Bar Ass'n Before the House Comm. on the Judiciary, 67th Cong., 2d Sess. 5, 11 (1922).

12 The final Senate report said: "The decisions of the United States Court of Claims are essentially declaratory in nature. . . ." S. REp. No. 1005, 73rd Cong., 2d Sess. 5 (1934). For a similar analogy see Hearings on H.R. 5623 Before the Subcomm. on the Judiciary, 70th Cong.,
} 
other side were two arguments ${ }^{83}$ of considerably more dubious merit based upon "scattered excerpts and inferences." Thus, the court concluded that legislative history failed to provide "a sound foundation" as to Congress' intent and that the issue probably never occurred to Congress at all. ${ }^{84}$ It is fair to say, however, that such limited materials as do exist tend to support the view that Congress considered the legislation as applicable to the Court of Claims.

Sovereign Immunity. Having demonstrated that, despite Congress' apparent failure to consider the question, the Declaratory

1st Sess. 21 (1928) (remarks of Professor Borchard). Still another argument made by the court was that the British and New York cases cited to illustrate the benefits of declaratory relief included claims against a government. See Hearing on Legislation Recommended by the Am. Bar Ass'n Before the House Comm. on the Judiciary, 67th Cong., 2d Sess., ser. 25, at 10 (1922) (testimony of A.B.A. witness H.W. Taft). See generally 69 CoNG. ReC. 1687, 2029 (1928) (remarks of Representative Celler and La Guardia).

A year following passage of the Declaratory Judgment Act, it was amended to exclude disputes "with respect to Federal taxes," Revenue Act of 1935, ch. 289, § 405, 49 Stat. 1014, 1027, so that the Act would not interfere with the orderly collection of taxes. See S. REP. No. 1240, 74th Cong., 1st Sess. 11 (1935); H. ReP. No. 1885, 74th Cong., Ist Sess. 13 (1935). For a criticism of the exception of all tax cases see Borchard 850-57. Tax disputes represent 35 percent of the Court of Claim's business. See Peartree, Statistical Analysis of the Court of Claims, 55 Geo. L.J. 541,549 (1967). Government contract and civil/military pay cases represent roughly 25 and 15 percent of the court's business, respectively. See id. Arguably, Congress' concern indicates that it must have viewed the Act as applicable to litigation under the Tucker Act and similar statutes waiving sovereign immunity, or else the amendment would have been unnecessary. The problem with this reasoning is that other tax jurisdictions exist in the federal courts and, at least now, refund suits in the district courts are not under $\S$ 1346(a)(2), but under $\$ 1346$ (a)(1) and without any limitation in amount.

${ }^{83}$ First, in House debate on one of the early bills, a statement was made by Committee Chairman Montague that the Act "applies to Federal district courts and the courts in the District of Columbia." 66 CoNG. Rec. 4874 (1925). But nothing in the context in which the statement was made suggests that it was meant to be a formal definition of the scope of the Act. Second, while it is now established that the Court of Claims is a constitutional court, see Glidden Co. v. Zdanok, 370 U.S. 530 (1962), in 1933 it was said to be a legislative court in Williams v. United States, 289 U.S. 553 (1933). Since the constitutionality of the Act was phrased in terms of its consistency with Article 1II, and since no reference was made to the lack of Article 111 restraints on legislative courts, this might be argued as an indication of Congress' intention not to include such courts. Nevertheless, the Supreme Court in Ex Parte Bakelite Corp., 279 U.S. 438,455 (1929), affirmatively recognized that the Court of Claims should be considered a "court of the United States" as that phrase is used in federal legislation.

3400 F.2d at 25 . The following contentions could be made: (a) the language of the 1934 Act, "courts of the United States," does not apply clearly on its face to the Court of Claims; (b) Twin Cities in effect dictates that the law existing at the time of the 1948 revision was against application of the Declaratory Judgment Act to the Court of Claims; (c) the 1948 revision was not intended to make great changes in the law; therefore, (d) the Act was not made applicable to the Court of Claims by the revision. The weakness of this argument lies in the fact that the Twin Cities decision was apparently never called to Congress' attention. Id. at 27 n.41. Even Profes- 
Judgment Act clearly applied on its face to the Court of Claims, the court was faced with the problem of reconciling two rules of statutory construction with the doctrine of sovereign immunity. On the one hand, the plain-meaning rule coupled with the legislative intent consideration indicated that, in the absence of an unmistakably clear legislative expression to the contrary, the Court of Claims was empowered to apply declaratory relief. ${ }^{85}$ On the other hand, the doctrine of sovereign immunity, and its corrollary proposition that any waiver must be strictly construed, ${ }^{86}$ seemed to support the

sor Borchard secms to have interpreted Twin Cities as holding only that declaratory relief cannot he given outside the court's general jurisdiction.

${ }^{35}$ The primary rule of intepretation of statutes is traditionally stated as being to give effect to the intention of the legislature. See Williams v. United States Fidelity and Guaranty Co., 236 U.S. 549 (1915). This intention is often unclear; therefore, numerous rules of statutory construction, many of which are conflicting, have been formulated. For a list of 28 conflicting rules see Llewellyn, Remarks on the Theory of Appellate Decision and the Rules or Canons About How Statutes are to be Construed, 3 VAND. L. Rev. 395, 401-06 (1950). The two canons most frequently employed are the plain meaning rule and the legislative intent rule. The plain meaning rule is simply one under which the courts will not look beyond the words of a statute if the statute is clear and unambiguous on its face. The exception is that if the literal construction of a statute will lead to an absurd or unreasonable result, then extrinsic materials will be utilized in order to ascertain the true intention of the legislature. Compare United States v. Missouri Pac. Ry., 278 U.S. 269 (1929) with Crooks v. Harrelson, 282 U.S. 55, 60 (1930). At the federal level the rule is seldom applied in its full vigor. Note, Trends in the Use of Extrinsic Aids in Statutory Interpretation, 3 VAND. L. REv. 586, 595 (1950). Therefore, the legislative intent rule is dominant today, and the main problems concern the proper weight to be given the various extrinsic aids in ascertaining the legislature's intent. Even language clear on its face will not be followed if a contrary intent appears in legislative history. See United States v. Dickerson, 310 U.S. 554, 562 (1940). However, where legislative history of the statute involved is found ambiguous and unconvincing, it appears that the plain meaning rule will be applied. See Fourco v. Transmira Prods. Corp., 353 U.S. 222, 227-28 (1957); United States v. National City Lines, 337 U.S. 78, 80-84 (1949); Ex Parte Collett, 337 U.S. 55, 61 (1949). See generally Horack, Congressional Silence: A Tool of Judicial Supremacy, 25 TEXAS L. REV. 247 (1947); Jones, The Plain Meaning Rule and Extrinsic Aids in the Interpretation of Federal Statutes, 25 WASH. U.L.Q. 2 (1939); MacCallum, Legislative Intent, 75 YALE L.J. 754 (1966).

${ }^{26}$ See, e.g., Soriano v. United States, 352 U.S. 270, 276 (1957); Danning v. United States, 259 F.2d 305 (9th Cir. 1958), cert. denied, 359 U.S. 911 (1959); Wells v. United States, 214 F.2d 380 (5th Cir.), cert. denied, 348 U.S. 855 (1954).

The tradition of strict interpretation of statutes waiving the immunity of the United States to suit seems to have been established in the early cases under the Court of Claims Act. See, e.g., Borchard, Government Liability in Tort, 34 YALE L.J. 1, 28-41 (1924). Arguably, however, once the government has waived immunity to suit by statute, suability rather than immunity should be the assumption. There now appears to be such an assumption when a federal agency, rather than the United States itself, is the defendant. See Keifer \& Keifer v. Reconstruction Fin. Corp., 306 U.S. 381 (1939): While the Keifer case marks the beginning of a series of cases expressing misgivings about sovereign immunity, the policy has been irregular. In 1941, Justice Stone stated that "consent, since it is a relinquishment of a sovereign immunity, must be strictly interpreted." United States v. Sherwood, 312 U.S. 584, 590 (1941). But three years later the 
rationale of $T^{\prime}$ 'in Cities because legislative history revealed no express Congressional intent that the Act applied to the Court of Claims. The decision in Twin Cities, however, was based on an assumption that by permitting suits theretofore barred from the court's consideration, the Act would expand its jurisdiction and thereby constitute a consent to be sued. This assumption was shown to be erroneous in that, by limiting declaratory relief to actions directed toward a money judgment, the Act could be construed so as not to alter the court's subject-matter jurisdiction. The question became, therefore, exactly how express must a waiver of sovereign immunity be when only a new procedural $^{87}$ vehicle of relief is afforded. Should the doctrine of sovereign immunity require, in addition to unambiguous statutory language, an affirmative showing of congressional intent? ${ }^{88}$

court found that a waiver of sovereign immunity $b_{y}$ the federal government in a state eourt could te "implied" from a grant of state court jurisdiction in actions to partition Indian lands in which the United States was held to be a "necessary party." United States v. Hellard, 322 U.S. 363, 368-69 (1944). And in Canadian Aviator, Ltd. v. United States, 324 U.S. 215 (1945), the Court construed the Putlic Vessels Act of 1925 literally, stating that "Congressional adoption of broad statutory language authorizing suit was deliberate and is not to te thwarted by an unduly restrictive interpretation." Id. at 222. In 1949, in its first decision under the Federal Tort Claims Act, the Court interpreted the act liberally as applying to a soldier hurt while on furlough. See Brooks v. United States, 337 U.S. 49, 51 (1949). Two years later, Justice Douglas stated that the liability of the United States was not to be whittled down "by restrictive and artificial distinctions." Warren v. United States, 340 U.S. 523, 530 (1951). In the following term, however, construing the Suits in Admiralty Act and the Clarification Act with rigor, the Court explained: "While, as the court below pointed out, legislation for the benefit of seamen is to be construed liberally in their favor, it is equally true that statutes which waive immunity of the United States from suit are to be construed strictly in favor of the sovereign." McMahon v. United States, 342 U.S. 25, 27 (1951). It is evident, therefore, that there is no consistent policy of interpretation in actions against the United States, and any statement to the effect that a waiver of sovereign immunity must be strictly construed is certainly tenuous.

${ }^{87}$ The operation of the Declaratory Judgment Act is procedural only and does not attempt to change the essential requisites for the exercise of federal jurisdiction. Skelly Oil Co. v. Phillips Petroluem Co., 339 U.S. 667, 673-74 (1946); Colegrove v. Green, 328 U.S. 549 (1946); Great Lakes Dredge \& Dock Co. v. Huggman, 319 U.S. 293 (1943); Aetna Life Ins. Co. v. Haworth, 300 U.S. 227, 240 (1937); Ashwander v. T.V.A., 297 U.S. 288 (1935). A procedural device is usually thought of as one enabling the courts to treat in a different manner a claim the subject matter of which is already legally protected. See BORCHARD 15. The distinction between jurisdiction and procedure was emphasized in Guaranty Trust Co. v. Hannay \& Co., (1915) 2 K.B. 536, 563 (C.A.), where it was said: "But if its only effect is to provide that the court may deal with a matter with which it can already deal in a different manner under different circumstances and when brought before it by a different person, it is, in my opinion, only dealing with practice and procedure and is intra vires . . . ." It would seem, therefore, that declaratory relief should te unavilable in those cases where it would have the effect of extending the court's subject-matter jurisdiction. But see Developments in the Law-Declaratory Judgments, 19411949, 62 HARV. L. REV. 787, 789 n. 14 (1949).

- ${ }^{\text {ss }}$ Under the doctrine of sovereign immunity it is usually considered that the government's 
Apparently, the court felt that the express language of the Act should control in such cases in the absence of a contrary legislative intent. Because the same conclusion would result from an application of the usual rules of statutory construction, the doctrine of sovereign immunity was, in effect, rendered inoperative. Thus, the court could say that "we do not require, as the court in Twin Cities did, a totally unambiguous Congressional statement vesting us with the authority to grant declaratory relief against the United States." "The broader implication may be that the doctrine of sovereign immunity will be applied with less rigor in cases involving grants of only procedural advantages..$^{\text {\%0 }}$ If the doctrine of sovereign immunity is merely a rule of construction giving rise to a presumption which aids in the determination of legislative intent, the court may be willing to presume less, and to search more diligently for Congress' intentions. In any event, the King court was able to conclude that the original 1934 Act adequately empowered it to render declaratory judgments. Alternatively, the court held that the clear language of the 1948 revision was controlling despite possible discrepancies with the original Act. ${ }^{91}$

The Tax Issue. There remained in King, however, the further question of whether the action was one "with respect to federal taxes," a category expressly excluded from the Declaratory Judgment Act.92

consent to be sued must be found in legislative enactments, see United States v. Sherwood, 312 U.S. 584, 586 (1941); that "the courts may not extend the waiver of immunity [from suit] beyond the letter of authority given by the statute," Hobby v. Hodges, 215 F.2d 754, 757 (10th Cir. 1954); and that "such waiver may not be implied in the construction of an ambiguous statute." General Mut. Ins. Co. v. United States, 119 F. Supp. 352, 354 (N.D.N.Y. 1953). Although at least one court has held it to be primarily a matter of legislative intent, see Cyrus v. United States, 132 F. Supp. 300, 301 (D. Mass. 1955), it does not appear that any court has ever required a showing in legislative history of Congressional intent to be sued when the statute on its face permits such suits. The reason is that in most statutes waiving immunity such intent is apparent from a reading of the act as a whole. However, while the Declaratory Judgment Act on its face applies to the Court of Claims, it is not obvious that Congress so intended because only by cross reference to 28 U.S.C. $\S 451$ (1964) does 28 U.S.C. $\$ \S 2201-02$ (1964) explicitly apply to the Court of Claims. In addition, Section 451 was added subsequent to the passage of the Act, and there is nothing to indicate that it was intended to be any more than a change in language.

s" 390 F.2d at 910 .

${ }^{\circ}$ Heretofore, courts have interpreted sovereign immunity somewhat less strictly in procedural matters. See Crown Coat Front Co. v. United States, 386 U.S. 503 (1967); United States v. Yellow Cab Co., 340 U.S. 543 (1951); United States v. Aetna Cas. \& Sur. Co., 338 U.S. 366 (1949).

9' Accord, Continental Cas. Co. v. United States, 314 U.S. 527, 530 (1942); United States v. Bowen, 100 U.S. 508, 513 (1879).

"See note 1 supra. 
The court considered the plaintiff's tax motives irrelevant because his request required merely a declaration of a right to have his military records changed rather than an interpretation of a tax statute. While courts have failed to delineate clearly the boundaries of a federal tax case, the court in King seemed to suggest that it requires both a request for the express determination of plaintiff's tax liability and an interpretation and application of the Internal Revenue Code. ${ }^{93}$ From an examination of the facts of decided cases, it appears that a simpler definition might have been given" - namely, an action "with respect to federal taxes" involves a dispute with tax officials as to petitioner's tax liability. ${ }^{95}$ Accordingly, it seems doubtful whether an action against anyone other than a tax official or the federal government could ever be considered a "tax case." This point is illustrated by Stern \& Co. v. State Loan \& Finance Corp. ${ }^{96}$ in which a district court adjudicated a breach of contract claim. Although not determining tax consequences, the facts litigated had a direct bearing on tax liability. Since no dispute with tax authorities was involved, however, the court was not precluded from exercising its Tucker Act jurisdiction. If, however, the plaintiff had chosen to bring a declaratory action against the Commissioner, suit should have been dismissed. Likewise, while the decision in King was correct in that the dispute concerned a determination by an Army official, declaratory relief would have been denied had the action focused on the threatened erroneous acts of the Internal Revenue Department. For example, in Wilson v. Wilson,"

93 390 F.2d at 914: "The determination which plaintiff requests is not a determination of his tax liability; the interpretation and application of INT. Rev. CODE OF 1954, § 104(a)(4) . . . is totally irrelevant to the question he seeks to place before us."

94 The court's test is somewhat misleading because an action may be one "with respect to taxes" even though the case does not turn on the interpretation of tax statutes. For example, if a dispute arose between the Commissioner and a taxpayer as to whether the latter was married, and the taxpayer brought an action against the Commissioner to declare his marriage valid thereby entitling him to the marital deduction, the action would clearly be a tax case even though the court might be concerned primarily with the interpretation of the state marriage laws. In other words, courts must often resort to non-tax statutes and even common law to determine tax liability. See, e.g., Prince v. United States, $127 \mathrm{Ct}$. Cl. 612, 617 (1954).

${ }^{95}$ An obvious class of suits falling within this definition are those for a declaratory judgment with respect to taxes alleged to have been erroneously assessed. See, e.g., Farmer v. Hooks, 194 F. Supp. 1, 2 (E.D. Ky. 1961) (suit dismissed as being beyond court's jurisdiction); Sweeney v. United States, 285 F.2d 444, 447 (Ct. Cl. 1961) (same).

${ }^{96} 205$ F. Supp. 702, 706 (D. Del. 1962).

${ }^{97} 141$ F.2d 599 (4th Cir. 1944). In Wilson, the Commissioner of Revenue informed plaintiff that the profits of a certain enterprise would be accredited to his account and that he would be taxed as though he were the sole owner. Claiming that the enterprise was a partnership in which he and his wife and daughter all had interests, plaintiff brought suit against the Commissioner 
involving an action brought against the Commissioner for a declaration of plaintiff's interest in a supposed family partnership and of his right to be taxed accordingly, suit was apparently dismissed as being one with respect to taxes. ${ }^{98}$ It seems clear, therefore, that a petitioner can avoid the tax case exception by framing his request for declaratory relief in a manner so as not to involve a direct dispute with revenue officers. ${ }^{99}$

Statute of Limitations. The decision in King, nevertheless, left unanswered a number of questions. Presently, the statute of limitations for the Court of Claims runs for six years ${ }^{100}$ from the time when all events have occurred which entitle plaintiff to payment as claimed. ${ }^{101}$ Arguably, the period should now start from the time when

and others for a declaration of the interests the supposed partners owned and of his right to be taxed according to the court's finding. The court held that "it was a suit to control them in the discharge of their official duties and hence a suit against the United States with respect to a matter as to which it had not consented to be sued." Id. at 600 . Since the court of appeals has jurisdiction to hear tax cases against the Government following a timely refund claim, the only possible basis for the court's holding was that the action constituted a suit "with respect to federal taxes."

"Accord, England v. United States, 261 F.2d 455 (7th Cir. 1958) (action to declare documents of no legal effect); Carmichael v. United States, 245 F.2d 676 (5th Cir. 1957) (action to declare taxpayer's status as self-employed); Pilip v. United States, 186 F. Supp. 397 (D. Alaska 1960) (action to declare that plaintiff was owner of certain property as tenant by the entirety and that lien filed by defendants did not attach to such property). But see Bulloch v. Latham, 306 F.2d 45 (2d Cir. 1962) (action against tax authorities for declaration that certain property helonged to plaintiff-jurisdiction upheld); Botta v. Scanlon, 288 F.2d 504 (2d Cir. 1961) (action against tax authorities to have assessment declared void-jurisdiction upheld); Tomlinson v. Smith, 128 F.2d 808 (7th Cir. 1942) (federal taxes exception held not applicable to suit by third party seeking to protect a lien); Pettengill v. United States, 205 F. Supp. 10 (D. Vt. 1962) (declaratory action seeking to free certain property owned by plaintiffs as tenants by the entirety from government tax liens).

" Because the exclusion of federal tax cases is couched in very general terms, it might seem that a broad, non-technical meaning should be given in order to effect Congress' purpose. Accordingly, a contention could be made that "federal tax cases" means those, such as King, in which the direct effect of a declaratory judgment would be to alter plaintiff's tax liability. However, this view would encompass suits obviously not within Congress' contemplation, beeause in any suit for a declaration that $\mathrm{A}$ owes money to $\mathrm{B}$, for example, significant tax consequences to $\mathrm{B}$ may be involved. It would also require considerable judicial speculation as to a taxpayer's primary motivations. Professor Borchard states that "the law or court has no concern with the motive of the plaintiff for bringing the action." BORCHARD 15.

${ }^{100} 28$ U.S.C. $\$ 2501$ (1964).

${ }^{101}$ See Oceanic S.S. Co. v. Unitcd States, 165 Ct. Cl. 217, 225 (1964). Stated differently, "A cause of action accrues for purposes of the statute of limitations when a suit may first be legally instituted thereon. . . ." Ball v. United States, 137 F. Supp. 740, 742 (Ct. Cl. 1956); $c f$. United States v. Wurts, 303 U.S. 414, 418 (1938); United States ex rel. Louisville Cement Co. v. 1CC, 246 U.S. 638, 644 (1918). In most instances, this means that a claim accrues for purposes of limitations when a money judgment may first be legally instituted. However, the problem is 
the right to declaratory relief first accrues. ${ }^{102}$ This view was given support by the Second Circuit in American-Foreign Steamship Corp. v. United States. ${ }^{103}$ In early 1946, the Government began chartering for hire many war-built vessels. Later, these charters were cancelled, and the plaintiffs were offered a more expensive arrangement, which they signed under protests of illegality. When suits were instituted for refunds, plaintiffs contended that the two-year limitation of the Suits in Admiralty Act ran from the time of the final audit of the new charter agreements, when refunds of all overpayments became due. The court held, however, that the running of the statute began after the signing of the new contracts, when action for declaratory relief could have been sought, or, alternatively, from the first payment of additional charter hire, when payment could have been refused forcing the Government to sue. The court's hesitancy in its first holding was not without reason. Not only was it contrary to the majority view ${ }^{104}$ but, in addition, it would transform a mere preventive remedy ${ }^{105}$ into a mandatory action in those instances where a claim for money could not mature before the running of the statutes. Additionally, in the latter cases it would encourage the piecemeal litigation of claims ${ }^{106}$ where the claimant prefers to bring action only upon the complete maturing of the dispute. ${ }^{107}$ Following the Second Circuit would seem,

somewhat more difficult in operating-differential contracts where accountings occur annually, with a final accounting at the end of the ten-year period. Although an action for money may be brought after the completion of an annual accounting, the precise amount of the government's liability is uncertain because of a recapture provision which cannot be determined until the final accounting. Apparently for this reason, the court in Oceanic held that the statute of limitations does not run until the final accounting has been completed. In King, the court expressly avoided the question of "whether the availability of declaratory relief would require a reevaluation of the Oceanic holding." 390 F.2d at 898 n.6.

${ }^{102}$ A leading case in support of the rule that the statute should run from the time a justiciable controversy arises is Pollack v. Josephy, 162 Misc. 238, 294 N.Y. S. 219 (Sup. Ct. 1937) (plaintiff s right to an accounting under a contract with defendant).

${ }^{103} 291$ F.2d 598 (2d Cir.), cert. denied, 368 U.S. 895 (1961). Compare Luckenbach S.S. Co. v. United States, 312 F.2d 545 (2d Cir. 1963) (declaration of non-liability).

104 See Developments in the Law-Declaratory Judgments, 194/-1949, 62 HARv. L. REv. 787, $830-32$ (1949).

${ }^{\text {tos }}$ Declaratory relief is a preventive remedy in the sense that it helps to "avoid accrual of avoidable damages to one not certain of his rights ...." E. Edelmann \& Co. v. Triplc-A Specialty Co., 88 F.2d 852, 854 (7th Cir.), cert. denied, 300 U.S. 680 (1937).

105 "There is a general rule against splitting a cause of action. . . . And to ask for a declaration for the breach of a contract, and in a subsequent proceeding asking for damages, would seem to violate the spirit of that rule . . ." Beatty v. Chicago B. \& Q. R. R., 49 Wyo. 22, 38, 52 P.2d 404, 409 (1935) (an action for damages was available, however, at time declaratory suit was brought).

${ }^{107}$ For example, in a subsidy contract operating between the years 1970 and 1980 , if the annual 
therefore, to be an unnecessary and shortsighted action. To mitigate this seemingly harsh position the court might hold that the statute of limitations should run separately for money and declaratory relief actions, depending on when the right to each originally accrues. The trend, however, is to permit suits for declaratory judgments until the right to coercive relief has itself been extinguished. ${ }^{108}$ This does not contravene the statute's policy of preventing unfair surprise, because the possibility of declaratory relief would not subject the Government to undue uncertainty so long as a money-judgment action is available. ${ }^{109}$ For these reasons, the wiser view is that the availability of declaratory relief in the Court of Claims should not affect the running of the statute of limitations. ${ }^{110}$

\section{ConCLUSION}

Whether the court's remedial powers will ever be expanded beyond the express limits of King is merely speculative, but a reasonable contention can be made that it should. While recognizing that "further relief" ancillary to a declaratory decree is expressly authorized by the Declaratory Judgment Act, ${ }^{\prime \prime}$ the court left undecided the question of whether specific relief, such as an injunction, could be rendered subsequent to a dishonored declaratory judgment. The expansion of the court's subject-matter jurisdiction would not be involved, because the original claim for declaratory relief would have to be in pursuit of a money judgment. Since the statute on its face permits such coercive relief in order to render effective a court's decrees, the reasoning in King supports the availability of such supplemental relief. Nor would this run counter to the court's present policy of granting not only money judgments but, in addition, "any incidental relief in equity in aid of such a judgment." 112 For instance, it has been held that it is within a court's

accounting for the first year were completed in 1972, a ship operator would have to bring suit for money or declaratory relief prior to 1978 to avoid barring his cause of action, even though he might prefer to bring a single action on the entire contract after the final accounting in 1980 or thereafter.

${ }^{108}$ See note 104 supra.

in See C. Preston \& G. Newsom, Limitation of Actions (1943).

110 See generally Comment, Mandatory Administrative Proceedings and Statutes of Limitations in Governnent Contract Cases: A Three-Way Conflict, 53 VA. L. Rev. 150(1967); Developnients in the Law-Statutes of Limitations, 63 HARV. L. REv. 1177 (1950).

"I 28 U.S.C. \$ 2202 (1964). "Further relief" means coercieve relief. BoRCHARD 441.

"' Blanc v. United States, 244 F.2d 708, 709 (2d Cir.), cert. denied, 355 U.S. 874 (1957). 
jurisdictional powers to reform a contract and enter a money judgment on the contract as reformed. ${ }^{113}$ On the other hand, it would conflict with the judicial hesitancy, as noted in King and Jones, of directly coercing public officials. Perhaps it could be argued that sueh relief requires express congressional approval in both statutory language and legislative history of the Act. The deeision on this issue may, then, hinge on the Court's attitude toward the doctrine of sovereign immunity, and this, in turn, should prove enlightening as to the strength and viability of this frequently excoriated doctrine. ${ }^{144}$

${ }^{113}$ See Cramp \& Sons v. United States, 239 U.S. 221 (1915); United States v. Milliken Imprinting Co., 202 U.S. 168 (1906).

${ }^{11}$ In 1967, a bill was introduced in Congress which would confer some equity jurisdiction upon the Court of Claims by authorizing it to implement its judgments for compensation of claims against the United States. See S. 1704, 90th Cong., 1st Sess. (1967). 